
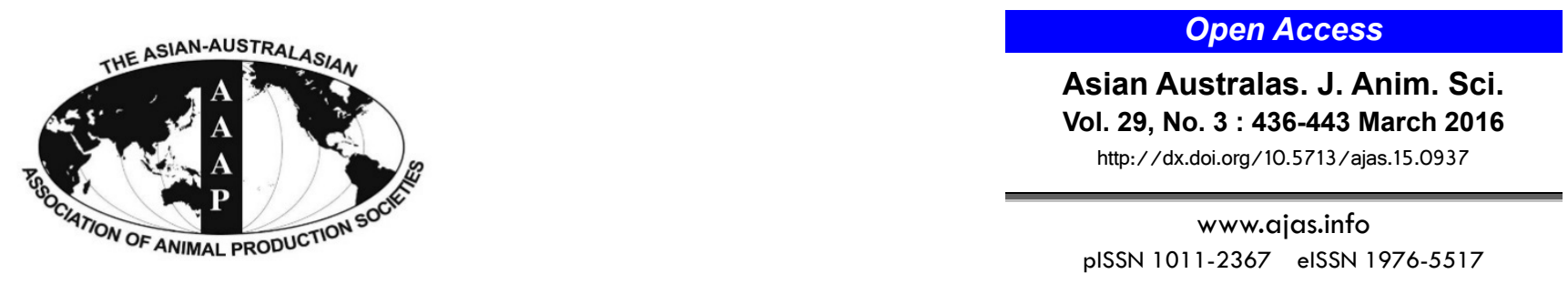

\title{
Effects of Ambient Temperature on Growth Performance, Blood Metabolites, and Immune Cell Populations in Korean Cattle Steers
}

\author{
H. J. Kang1, I. K. Lee', M. Y. Piao', M. J. Gu' ${ }^{1}$, C. H. Yun ${ }^{1,3}$, H. J. Kim ${ }^{1}$, K. H. Kim ${ }^{2,3}$, and M. Baik ${ }^{1,3, *}$ \\ ${ }^{1}$ Department of Agricultural Biotechnology and Research Institute of Agriculture and Life Sciences, \\ College of Agriculture and Life Sciences, Seoul National University, Seoul 151-921, Korea
}

\begin{abstract}
Exposure to cold may affect growth performance in accordance with the metabolic and immunological activities of animals. We evaluated whether ambient temperature affects growth performance, blood metabolites, and immune cell populations in Korean cattle. Eighteen Korean cattle steers with a mean age of 10 months and a mean weight of $277 \mathrm{~kg}$ were used. All steers were fed a growing stage-concentrate diet at a rate of $1.5 \%$ of body weight and Timothy hay ad libitum for 8 weeks. Experimental period 1 (P1) was for four weeks from March 7 to April 3 and period 2 (P2) was four weeks from April 4 to May 1 . Mean $\left(8.7^{\circ} \mathrm{C}\right)$ and minimum $\left(1.0^{\circ} \mathrm{C}\right)$ indoor ambient temperatures during $\mathrm{P} 1$ were lower $(\mathrm{p}<0.001)$ than those $\left(13.0^{\circ} \mathrm{C}\right.$ and $6.2^{\circ} \mathrm{C}$, respectively) during $\mathrm{P} 2$. Daily dry matter feed intake in both the concentrate diet and forage groups was higher $(\mathrm{p}<0.001)$ during P2 than P1. Average daily weight gain was higher $(\mathrm{p}<0.001)$ during P2 $(1.38 \mathrm{~kg} / \mathrm{d})$ than P1 $(1.13 \mathrm{~kg} / \mathrm{d})$. Feed efficiency during P2 was higher $(\mathrm{p}=0.015)$ than P1. Blood was collected three times; on March 7, April 4, and May 2. Nonesterified fatty acids (NEFA) were higher on March 7 than April 4 and May 2. Blood cortisol, glucose, and triglyceride concentrations did not differ among months. Blood CD4+, CD8+, and CD4+CD25+ T cell percentages were higher, while $\mathrm{CD} 8+\mathrm{CD} 25+\mathrm{T}$ cell percentage was lower, during the colder month of March than during May, suggesting that ambient temperature affects blood $\mathrm{T}$ cell populations. In conclusion, colder ambient temperature decreased growth and feed efficiency in Korean cattle steers. The higher circulating NEFA concentrations observed in March compared to April suggest that lipolysis may occur at colder ambient temperatures to generate heat and maintain body temperature, resulting in lower feed efficiency in March. (Key Words: Korean Cattle, Ambient Temperature, Growth, Feed Efficiency, Blood Metabolites, Immune Cells)
\end{abstract}

\section{INTRODUCTION}

Exposure of feedlot animals to hot or cold stress reduces growth and feed efficiency (Ames et al., 1980). Cold climate during winter and exposure to cold stress induces metabolic acclimatization, resulting in decreased animal performance and production efficiency (Young, 1981; Birkelo et al., 1991). Temperature stress seemingly changes metabolic and endocrinal status of animals. For example, cattle exposed to acute cold have increased concentrations

\footnotetext{
* Corresponding Author: M. Baik. Tel: +82-2-880-4809, Fax:+82-2-873-2271, E-mail: mgbaik@snu.ac.kr

${ }^{2}$ Graduate School of International Agriculture Technology, Seoul National University, Pyeongchang 232-196, Korea.

${ }^{3}$ Institute of Green Bio Science \& Technology, Pyeongchang 232196, Korea.

Submitted Nov. 17, 2015; Revised Dec. 21, 2015; Accepted Jan. 12, 2016
}

of plasma corticosteroids (Alvarez and Johnson, 1973) and circulating nonesterified fatty acid (NEFA) concentrations (Broucek et al., 1987; Nonnecke et al., 2009).

Low environmental temperature can cause cold stress, which affects the immune system and thus animal health. The effect of a cold environment on the immune response has been studied in other than cattle. For example, pigs in a cold environment caused increase in serum adrenocorticotropic hormone and cortisol concentrations coincident with tissue cytokine mRNA levels (Frank et al., 2003). Cold stress increases in vivo proinflammatory cytokine gene expression, including interleukin mRNA, in chicken (Hangalapura et al., 2005). However, limited data are available on the effect of a cold environment on the immune response in cattle.

Temperatures on the Korean peninsula increased by approximately $2^{\circ} \mathrm{C}$ during 1992 through 2004 due to a 
global warming (Ho et al., 2006), and hotter summers are expected in the future. In addition, global warming also caused colder winters in South Korea. Therefore, animal performance should have been greatly impacted by cold stress, as cattle sheds in Korea are generally of the open type. Little information is available on the effects of temperature on growth performance and the metabolic and immunological responses in Korean cattle steers. This study was performed to examine whether ambient temperature affects growth, feed efficiency, blood metabolites, and immune cell populations in Korean cattle steers.

\section{MATERIALS AND METHODS}

\section{Animals and feeding trial}

All experimental procedures involving animals were approved by the Seoul National University Institutional Animal Use and Care Committee (SNUIAUCC), Republic of Korea, and were conducted in accordance with the Animal Experimental Guidelines provided by SNUIAUCC.

Eighteen Korean cattle steers, with a mean age of 10 months and a mean weight of $277 \mathrm{~kg}$, were used. The study was conducted at the University Animal Farm of the College of Agriculture \& Life Sciences on the Pyeongchang campus of Seoul National University, South Korea. Experimental farm was covered by roof, and thus animal was protected from the rain. Doors were installed at both of barn, and animal was raised indoor. All steers were fed a growing stage- concentrate diet at approximately $1.5 \%$ of body weight using the DeLaval Alpro automatic feeding station (DeLaval, Tumba, Sweden) for 8 weeks. Feeding period 1 (P1) was from March 7 to April 3 and period 2 (P2) was from April 4 to May 1. The formula of concentrate diet is shown in Table 1. Timothy hay was fed ad libitum. Water was freely provided. The chemical composition of the feed is shown in Table 1. Daily feed intake of the concentrate diet was automatically recorded on an online Alpro system computer. An equal amount of hay was fed to each animal twice a day (8 AM and $6 \mathrm{PM}$ ), and the residual hay was weighed before the morning feeding. Samples of concentrate and hay were collected weekly and stored until analysis. Body weight was measured at 9 AM before feeding on the start date, and 4 and 8 weeks after feeding.

\section{Chemical composition analyses}

The chemical compositions (dry matter, crude protein, crude fat, ash, $\mathrm{Ca}$, and $\mathrm{P}$ ) of the concentrate diet and timothy hay were determined using an AOAC method (1990). The neutral detergent fiber and acid detergent fiber contents of the hay were analyzed using the sequential method with the ANKOM200 Fiber Analyzer (Ankom Technology Corp., Macedon, NY, USA) and reagents, as described by Van Soest et al. (1991).
Table 1. Ingredients of concentrate diet and composition of experimental diets for Korean cattle steers

\begin{tabular}{|c|c|}
\hline Items & $\% \mathrm{DM}$ \\
\hline \multicolumn{2}{|l|}{ Ingredients of concentrate diet } \\
\hline Ground corn & 15.8 \\
\hline Ground wheat & 18.0 \\
\hline Salt & 0.88 \\
\hline Molasses & 5.50 \\
\hline Wheat bran & 3.00 \\
\hline Corn flour & 5.00 \\
\hline Rice bran & 3.00 \\
\hline Cottonseed hulls & 1.50 \\
\hline Palm kernel meal & 10.0 \\
\hline Ammonium chloride & 0.15 \\
\hline Rapeseed meal & 2.22 \\
\hline Dried distilled grain- soluble & 9.38 \\
\hline Condensed molasses- soluble & 1.50 \\
\hline Corn gluten feed & 8.50 \\
\hline Limestone & 3.30 \\
\hline Copra meal & 10.0 \\
\hline Porphyry & 2.00 \\
\hline Mineral/vitamin premix ${ }^{1}$ & 0.25 \\
\hline Total & 100.0 \\
\hline \multicolumn{2}{|l|}{ Chemical composition } \\
\hline \multicolumn{2}{|l|}{ Concentrate diet } \\
\hline DM & 87.8 \\
\hline $\mathrm{CP}$ & 14.5 \\
\hline Fat & 3.23 \\
\hline Ash & 7.80 \\
\hline $\mathrm{Ca}$ & 1.43 \\
\hline $\mathrm{P}$ & 0.50 \\
\hline \multicolumn{2}{|l|}{ Timothy hay } \\
\hline $\mathrm{DM}$ & 90.7 \\
\hline $\mathrm{CP}$ & 7.84 \\
\hline Fat & 2.13 \\
\hline Ash & 8.05 \\
\hline $\mathrm{Ca}$ & 0.24 \\
\hline $\mathrm{P}$ & 0.20 \\
\hline $\mathrm{ADF}$ & 35.5 \\
\hline $\mathrm{NDF}$ & 59.3 \\
\hline
\end{tabular}

DM, dry matter; CP, crude protein; ADF, acid detergent fiber; NDF, neutral detergent fiber.

${ }^{1}$ Mineral and vitamin premix contained vitamin A 2,650,000 IU, vitamin $\mathrm{D}_{3} 530,000 \mathrm{IU}$, vitamin E 1,050 IU, niacin 10,000 mg, Mn 4,400 mg, Zn 4,400 mg, Fe 13,200 mg, Cu 2,200 mg, iodine $440 \mathrm{mg}$, and Co, 440 $\mathrm{mg} / \mathrm{kg}$ of additive Grobic-DC (provided from Bayer Health Care, Leverkusen, Germany).

\section{Blood collection and temperature measurements}

Blood was collected three times; on March 7, April 4, and May 2, 2014, after a $9 \mathrm{~h}$ fast by jugular venipuncture into non-heparinized vacutainers $(20 \mathrm{~mL}$; Becton-Dickinson, Waltham, MA, USA) and ethylenediaminetetraacetic acid (EDTA)-treated vacutainers $(20 \mathrm{~mL})$. Some of the whole blood collected in the EDTA-vacutainers was used for the immune cell analysis. Serum and plasma were separated by 
centrifugation at $1,500 \times \mathrm{g}$ at $4{ }^{\circ} \mathrm{C}$ for $15 \mathrm{~min}$. The plasma and serum were subsequently stored at $-80^{\circ} \mathrm{C}$ until analysis.

Ambient and climate temperatures and relative humidity inside and outside the barn were recorded at $1 \mathrm{~h}$ intervals using three HOBO data loggers (Onset Computer Corp., Bourne, MA, USA), and monthly average values of minimum, mean, and maximum temperatures and humidity were calculated using the daily data.

\section{Blood analysis}

The analytical reagents for glucose, triglyceride (TG), high-density lipoprotein (HDL), low-density lipoprotein (LDL), cholesterol, total protein, glutamic oxaloacetic transaminase (GOT), glutamic pyruvate transaminase (GPT), creatinine, blood urea nitrogen, calcium, magnesium, and phosphorus were purchased from JW Medical (Seoul, Korea). The analytical reagents for the NEFA, phospholipid, and beta-hydroxy butyrate analyses were purchased from Wako Pure Chemical (Osaka, Japan). The analytical reagents for complements $\mathrm{C} 3$ and $\mathrm{C} 4$ were purchased from Sekisui (Osaka, Japan). All of these parameters were analyzed using an automated chemistry analyzer (Hitachi 7180 , Tokyo, Japan). Plasma cortisol was analyzed using a cortisol salivary HS enzyme-linked immunosorbent assay kit (cat. no. SLV4635; DRG Instruments, Marburg, Germany). The intra and interassay coefficients of variation for the cortisol kit were $4.0 \%$ and $4.6 \%$, respectively, using bovine plasma samples.

\section{Immune cell analysis}

A $100 \mu \mathrm{L}$ aliquot of whole blood was treated with $1 \mathrm{~mL}$ BD lysing buffer (Becton-Dickinson, USA) and incubated for $3 \mathrm{~min}$ at room temperature to analyze the immune cell characteristics. Total cell numbers were counted with a TC10 Automated Cell Counter (Bio-Rad, Hercules, CA, USA). Then, the granulocyte: lymphocyte ratio, identified by flow cytometry using the forward scatter (FSC) and side scatter (SSC) settings (Kampen et al., 2004), was calculated as a percentage of total cells. Leukocytes $\left(5 \times 10^{5}\right.$ cells $)$, stained with anti-bovine CD14-FITC and MHC class II DQ-PE antibodies for monocytes and B cells, respectively and CD4-Alexa647, CD8-PE, and CD25-FITC antibodies (AbD Serotec, Raleigh, NC, USA) for T cells, respectively, for $15 \mathrm{~min}$ at $4^{\circ} \mathrm{C}$, were analyzed by flow cytometry (Becton-Dickinson, USA) and FlowJo software (TreeStar, Ashland, OR, USA). Briefly, lymphocytes and monocytes were gated based on FSC-SSC setting and CD14 $4^{+} \mathrm{MHC}$ class II $\mathrm{DQ}^{+}$cells were analyzed as monocytes and $\mathrm{CD} 14^{-}$ MHC class II $\mathrm{DQ}^{+}$as $\mathrm{B}$ cells. T cells were analyzed with CD4 and/or CD8 positive among lymphocytes and then activated $T$ cells were identified as $\mathrm{CD} 25^{+}$cells.

\section{Statistical analysis}

All data are expressed as means \pm standard error of mean.
Differences in weather data among months were analyzed using one-way analysis of variance (ANOVA). Changes in the growth performance and blood parameters over time were analyzed by repeated-measures ANOVA with the Tukey-Kramer post-hoc test. A $p<0.05$ was considered significant. All statistical tests were performed using $R$ Studio for Windows software package (R Studio, Boston, MA, USA).

\section{RESULTS AND DISCUSSION}

\section{Climate conditions}

Experimental farm was covered by roof, and thus animal was protected from the rain. Doors were installed at both of barn, and animal was raised indoor. Thus, mild wind may affect wind-chill temperature. However, minimum indoor temperature was $1.0^{\circ} \mathrm{C}$ and $6.2^{\circ} \mathrm{C}$ on March and April, which are not within severe cold stress range. Thus, wind factor may be a minor climate variable. Mean $\left(8.7^{\circ} \mathrm{C}\right)$ and minimum $\left(1.0^{\circ} \mathrm{C}\right)$ indoor ambient temperature of March was lower $(\mathrm{p}<0.001)$ than that $\left(13.0^{\circ} \mathrm{C}\right.$ and $\left.6.2^{\circ} \mathrm{C}\right)$ of April, respectively. But, maximum temperature of March $\left(20.6^{\circ} \mathrm{C}\right)$ was not different from that of April $\left(21.4^{\circ} \mathrm{C}\right)$. Mean $\left(4.6^{\circ} \mathrm{C}\right)$, maximum $\left(10.6^{\circ} \mathrm{C}\right)$, and minimum $\left(-1.7^{\circ} \mathrm{C}\right)$ climate temperature of March was lower $(\mathrm{p}<0.001)$ than that $\left(9.8^{\circ} \mathrm{C}\right.$, $15.8^{\circ} \mathrm{C}, 3.4^{\circ} \mathrm{C}$ ) of April, respectively. Mean, maximum, and minimum relative humidity of March was not different from those of April (Table 2).

\section{Growth performance}

Daily intake of concentrate and forage was higher $(\mathrm{p}<0.001)$ during April (concentrate, $3.97 \mathrm{~kg}$ and forage, $3.71 \mathrm{~kg}$ ) than March (concentrate, $3.54 \mathrm{~kg}$ and forage, 3.34 $\mathrm{kg})$. Average daily gain was higher $(\mathrm{p}<0.001)$ during April $(1.38 \mathrm{~kg} / \mathrm{d})$ than March $(1.13 \mathrm{~kg} / \mathrm{d})$. Feed efficiency during

Table 2. Mean, maximum, and minimum values of ambient temperatures, climate temperatures, and relative humidity at March and April of 2014

\begin{tabular}{lcccc}
\hline Items & March $^{1}$ & April $^{2}$ & SE & $\mathrm{p}$ \\
\hline Ambient temperature $\left({ }^{\circ} \mathrm{C}\right)$ & & & & \\
$\quad$ Mean & 8.70 & 13.0 & 0.88 & $<0.001$ \\
$\quad$ Maximum & 20.6 & 21.4 & 0.38 & 0.58 \\
$\quad$ Minimum & 1.00 & 6.24 & 0.48 & $<0.001$ \\
Climate temperature $\left({ }^{\circ} \mathrm{C}\right)$ & & & & \\
$\quad$ Mean & 4.60 & 9.80 & 0.66 & $<0.001$ \\
$\quad$ Maximum & 10.6 & 15.8 & 0.81 & $<0.001$ \\
$\quad$ Minimum & -1.7 & 3.4 & 0.64 & $<0.001$ \\
Relative humidity $(\%)$ & & & & \\
$\quad$ Mean & 61.6 & 63.7 & 1.43 & 0.47 \\
$\quad$ Maximum & 87.0 & 88.0 & 0.97 & 0.63 \\
$\quad$ Minimum & 37.3 & 40.3 & 1.98 & 0.47 \\
\hline
\end{tabular}

SE, standard error.

${ }^{1}$ March 7 to April 3 (4 weeks). ${ }^{2}$ April 4 to May 1 (4 weeks). 
April $(0.18 \mathrm{~kg}$ gain $/ \mathrm{kg}$ feed $)$ was higher $(\mathrm{p}<0.02)$ than March (0.16 gain $/ \mathrm{kg}$ feed) (Table 3$)$. In this study, indoor ambient temperature affected both the growth and feed efficiency of Korean cattle steers. Weight gain and feed efficiency were lower during the colder month of March compared to April. Other studies have reported similar results; colder temperatures resulted in lower feed efficiency (Elam, 1970; Delfino and Mathison, 1991) and average daily gain (Birkelo et al., 1991). Cold stress has been categorized as "mild" $\left(0^{\circ} \mathrm{C}\right.$ to $\left.-6.7^{\circ} \mathrm{C}\right)$, "moderate" $\left(-7.2^{\circ} \mathrm{C}\right.$ to $\left.-13.9^{\circ} \mathrm{C}\right)$, and "severe" $\left(<-13.9^{\circ} \mathrm{C}\right)$ under dry winter cattle coat conditions (Grzych, 2010). Mader et al. (2010) suggested that animal susceptibility to stress varies more for cold stress than for heat stress dependent on breed, stage of animal's life cycle. Ambient temperatures well above the estimated lower critical value affect feedlot cattle growth performance (Webster, 1970; Young and Christopherson, 1974). Studies have suggested that energy requirements increased during winter or when animals are under cold stress due to the need to increase resting heat production to maintain body temperature by shivering or other thermogenic process (Young, 1983; Christopherson, 1985). Thus, the lower feed efficiency during March compared to April may have been due to the increased energy utilization for heat production at a colder ambient temperature. In results of our study, both climate condition and age effects may be compounded because climate effects
Table 3. Growth performance of Korean cattle steers at March and April of 2014

\begin{tabular}{lcccc}
\hline Items & March $^{1}$ & April $^{2}$ & SE & $\mathrm{p}$ \\
\hline Age (month) & 9.7 & 10.6 & 0.13 & \\
Body weight $^{3}(\mathrm{~kg})$ & 309 & 347 & 4.60 & $<0.001$ \\
Feed intake (DM) & & & & \\
$\quad$ Total daily feed intake (kg/d) & 6.88 & 7.68 & 0.10 & $<0.001$ \\
$\quad$ Daily concentrate intake (kg/d) & 3.54 & 3.97 & 0.06 & $<0.001$ \\
$\quad$ Daily forage intake (kg/d) & 3.34 & 3.71 & 0.05 & $<0.001$ \\
Average daily gain (kg/d) & 1.13 & 1.38 & 0.04 & $<0.001$ \\
Feed efficiency (gain/feed) & 0.16 & 0.18 & 0.004 & 0.02 \\
\hline
\end{tabular}

SE, standard error; DM, dry matter.

${ }^{1}$ March 7 to April 3 (4 weeks). ${ }^{2}$ April 4 to May 1 (4 weeks).

${ }^{3}$ Initial body weight was $277.1 \mathrm{~kg}$. Body weight was recorded at April 4 and May 2, respectively.

$\mathrm{N}=18$.

were compared at different growing period. Generally, the younger animal has higher feed efficiency. But, feed efficiency was higher at period 2 in older age. Thus, climate condition may be a major effect, and age effect may be minor since only one month difference between 9.7 and 10.6 months of age.

\section{Blood cortisol and metabolites}

Blood NEFA concentrations were higher during the colder month of March than those during April and May ( $p<0.05$; Figure 1), suggesting that lipolysis may occur at
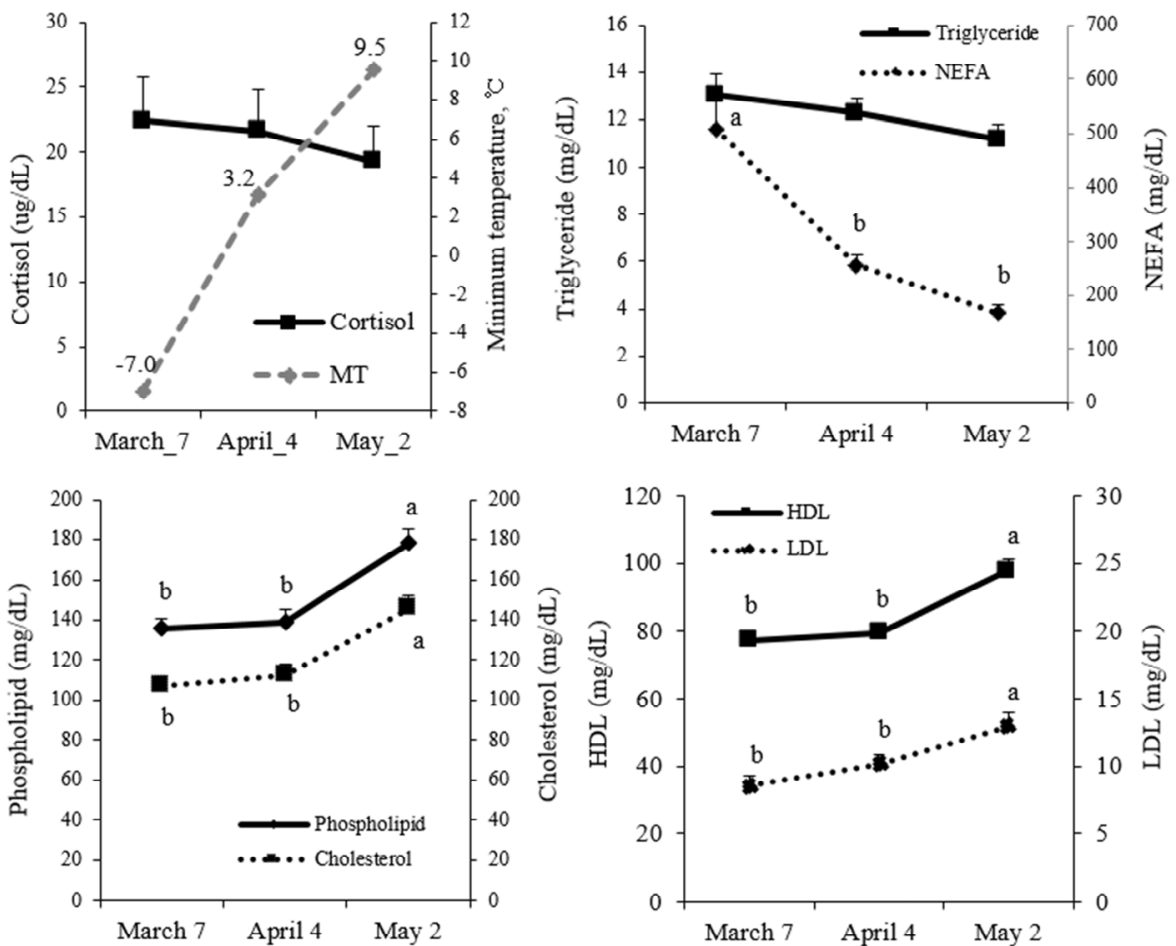

Figure 1. Serum cortisol and lipid metabolite concentrations in Korean cattle steers over several months. Values are means + standard error. Minimum ambient temperature (MT) is shown in the top-left panel. Mean values with different letters differ significantly ( $<<0.05$ ). NEFA, non-esterified fatty acid; HDL, high density lipoprotein; LDL, low density lipoprotein. 

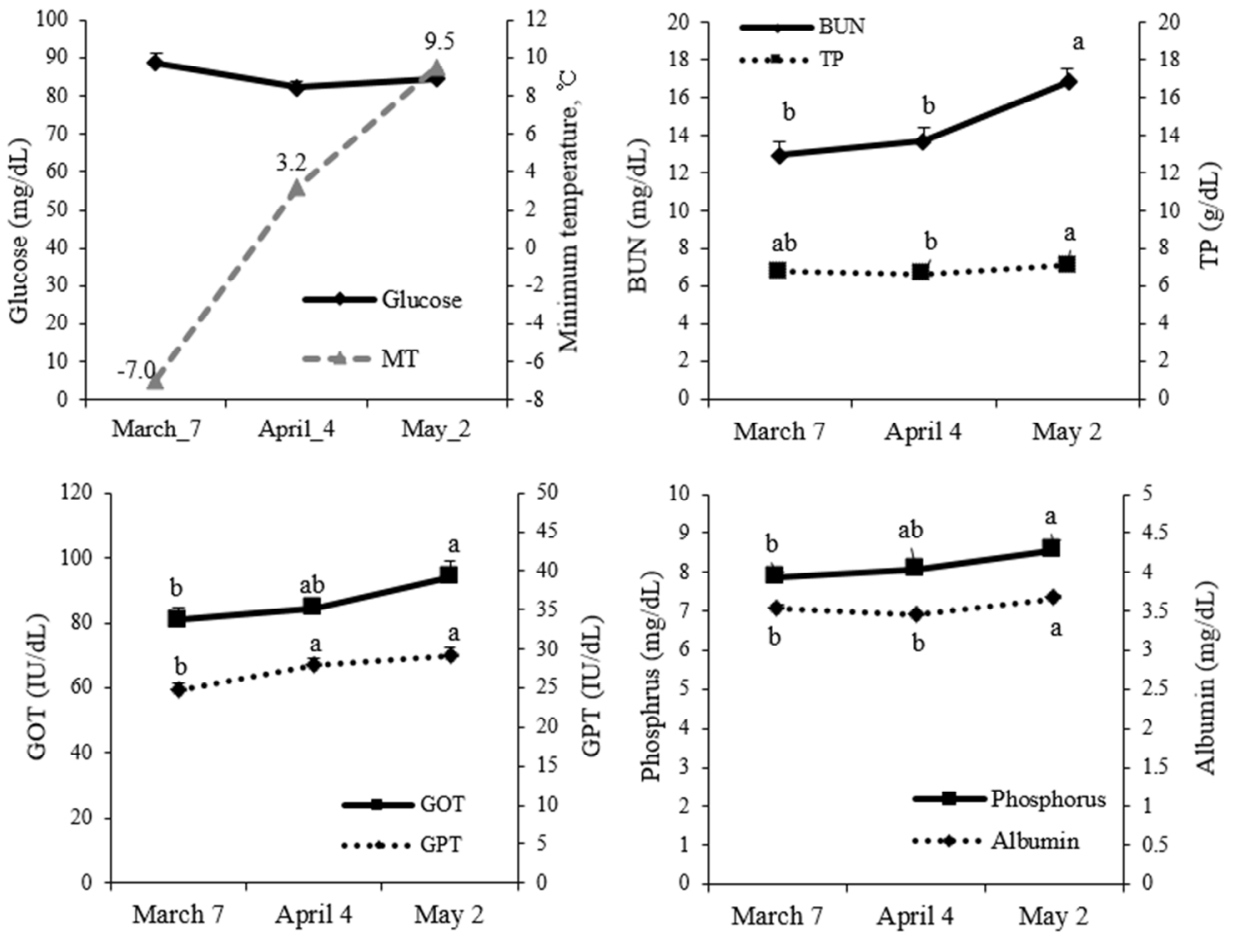

Figure 2. Serum concentrations of glucose, blood urea nitrogen (BUN), total protein (TP), glutamic oxaloacetic transaminase (GOT), glutamic pyruvate transaminase (GPT), albumin, and phosphorus in Korean cattle steers over several months. Minimum ambient temperature (MT) is shown in the top-left panel. Values are means+standard error. Mean values with different letters differ significantly $(\mathrm{p}<0.05)$.

colder ambient temperatures to generate heat for maintaining body temperature. However, cortisol concentrations were not changed. These results suggest that the decrease in NEFA concentration may not be regulated by cortisol. Blood NEFA concentrations in dairy cattle often increase when feed intake cannot support their energy requirements, requiring the mobilization of NEFA by lipolysis of fat depots to support energy demand (Bauman and Currie, 1980). Broucek et al. (1987) reported that NEFA concentrations increase under low temperature conditions. Calves in a cold environment $\left(4.7^{\circ} \mathrm{C}\right)$ also have higher NEFA concentrations than those in a warm indoor environment $\left(15.5^{\circ} \mathrm{C}\right.$; Nonnecke et al., 2006). Taken together, increased NEFA concentrations during colder weather may help generate energy to maintain body temperature and growth. Stress is generally accompanied by an increase in cortisol concentration, and cortisol concentrations increase under cold conditions (Khan et al., 1970; Takahashi et al. 1986). In our study, the minimum temperature $\left(1.0^{\circ} \mathrm{C}\right)$ during March may not have been sufficiently cold to stimulate cortisol secretion. Generally, amount of diet feed consumed significantly affects blood metabolites and hormone concentrations. Therefore, we collected blood after $9 \mathrm{~h}$ fasting to minimize such diet variation among animals. Mills and Jenny (1979) and Ward et al. (1992) reported that cortisol concentrations were increased during fasting. Thus, cortisol concentrations at fasting may be higher than that at feeding stage. Our study showed no significant difference in fasting cortisol concentrations between April and May. We cannot exclude that fasting condition masks temperature responses.

In the present study, blood concentrations of phospholipids, HDL, LDL, and cholesterol were lower during March and April than during May ( $<<0.05$; Figure 2). In rat study, cold stress decreased serum total cholesterol and HDL concentrations (Tsopanakis and Tesserommatis, 1991). Consistent with our study, cold-stressed broilers have lower serum total cholesterol, HDL, and LDL concentrations (Chen et al., 2012). Collectively, our results suggest that ambient temperature may affect lipoprotein metabolism.

In our study, blood concentrations of glucose, TG, and total protein were not different $(p>0.05)$ among months (Figures 1 and 2). Blood concentrations of urea nitrogen, GOT, GPT, phosphorus, and albumin were higher $(\mathrm{p}<0.05)$ during May than during March (Figure 2). Changes in these parameters due to cold stress or low temperature have not been reported previously.

\section{Immune cell populations}

Inflammatory responses are often associated with the induction of acute-phase reactants, such as the $\mathrm{C} 3$ and $\mathrm{C} 4$ 
compartments of the complement system (Ghazavi et al., 2013). In our study, blood $C 4$ levels were higher $(p<0.05)$ during March than April or May, whereas C3 level did not differ (Figure 3). Our results suggest that the C4 complement factor may be induced more during the colder March temperatures than other months. The functional significance of this change remains to be elucidated.

The granulocyte: lymphocyte ratio and $\mathrm{B}$ cell and monocyte populations did not differ among months. It is well known that glucocorticoids released during stressful events often modulate the immune system, including increases in the neutrophil: lymphocyte ratio and changes in the number of monocytes (Weber et al., 2004). Neutrophil: lymphocyte ratio changes occurred under acute and inflammatory conditions, such as weaning stress and tissue injury (Kim et al., 2011). It is probable that the ambient temperatures during March in the present study were not low enough to induce such changes.

The numbers of $\mathrm{CD}^{+}, \mathrm{CD}^{+}$, and $\mathrm{CD} 4^{+} \mathrm{CD} 25^{+} \mathrm{T}$ cells were higher $(\mathrm{p}<0.05)$, and the number of $\mathrm{CD}^{+} \mathrm{CD} 25^{+} \mathrm{T}$ cells was lower $(p<0.05)$, in March than in May (Figure 3). These results suggest that the number of helper $\mathrm{T}$ cells, cytotoxic $\mathrm{T}$ cells, and regulatory $\mathrm{T}$ cells are likely modulated during the colder month of March compared to May. T cells were increased significantly in the spleen of acute cold-stressed mice, whereas CD4+ and CD8+ cell
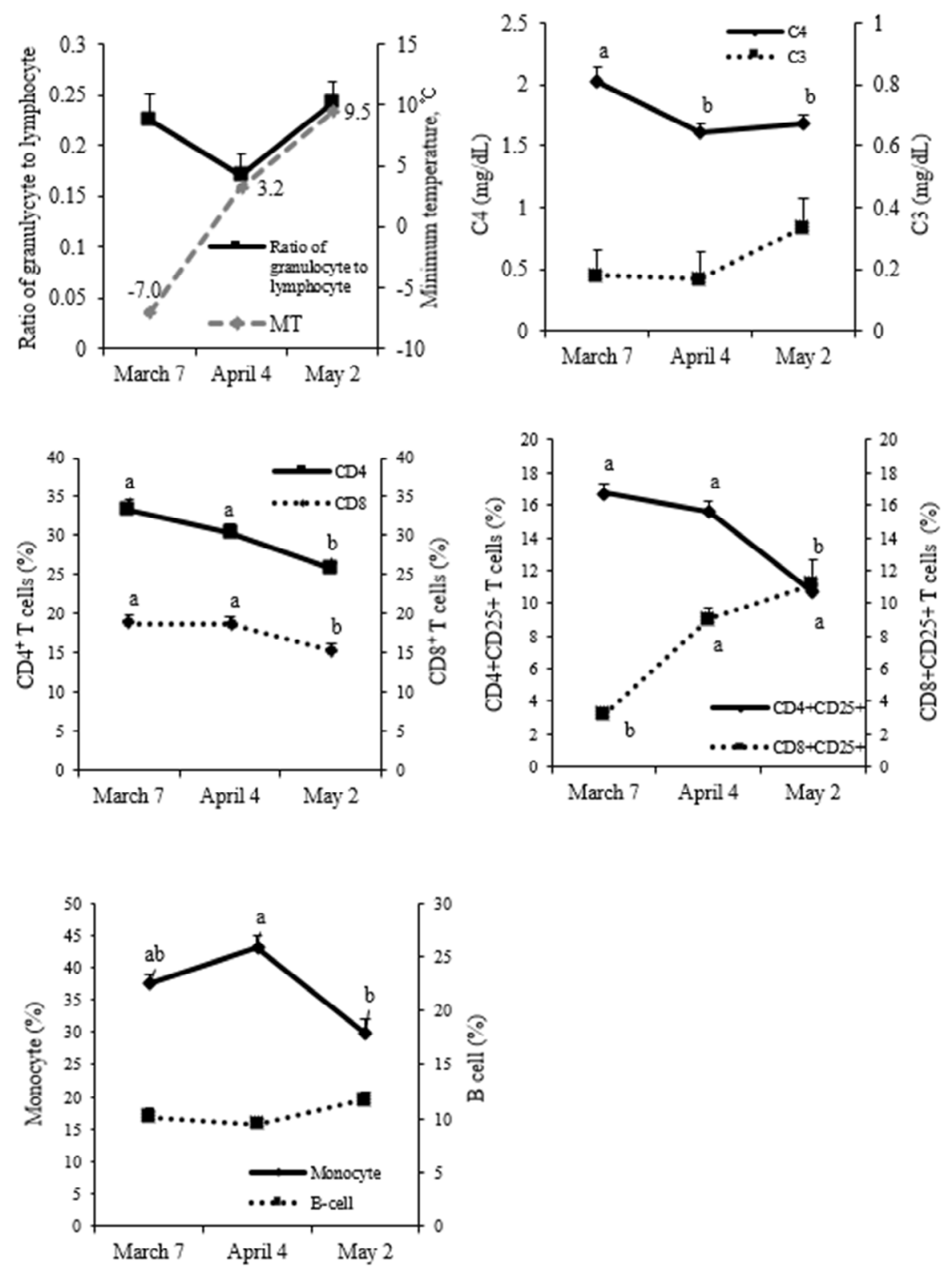

Figure 3. Serum concentrations of complement factors, the granulocyte: lymphocyte ratio, and monocyte, T cell, and B cell populations in Korean cattle steers over several months. Minimum ambient temperature (MT) is shown in the top-left panel. Values are means+ standard error. Mean values with different letters differ significantly $(\mathrm{p}<0.05)$. 
populations were minimally increased (Kizaki et al., 1995). Whether these changes in blood $\mathrm{T}$ cell populations are directly associated with ambient temperature must be clarified in cattle.

In conclusion, the minimum ambient temperature was lower in March $\left(1^{\circ} \mathrm{C}\right)$ than in April $\left(6^{\circ} \mathrm{C}\right)$. Daily weight gain and feed efficiency were lower in March than in April, suggesting that ambient temperature affects growth and feed efficiency in Korean cattle steers. Higher circulating NEFA concentrations during March compared to April suggest that lipolysis may occur at colder temperatures to generate heat to maintain body temperature. Blood CD4+, $\mathrm{CD} 8+$ and $\mathrm{CD} 4+\mathrm{CD} 25+\mathrm{T}$ cell populations were higher in March than in May, suggesting that ambient temperature affects blood $\mathrm{T}$ cell populations.

\section{CONFLICT OF INTEREST}

We certify that there is no conflict of interest with any financial organization regarding the material discussed in the manuscript.

\section{ACKNOWLEDGMENTS}

This study was supported by a grant from the Bioindustry Technology Development Program (No. 31302004-1-HD030), Ministry of Agriculture, Food, and Rural Affairs, Republic of Korea, and by the Next Generation BioGreen 21 Program (No. PJ01114001), Rural Development Administration, Republic of Korea.

\section{REFERENCES}

Alvarez, M. B and H. D. Johnson. 1973. Environmental heat exposure on cattle plasma catecholamine and glucocorticoids. J. Dairy Sci. 56:189-194.

Ames, D. R., D. R. Brink, and C. L. Willms. 1980. Adjusting protein in feedlot diets during thermal stress. J. Anim. Sci. 50:1-6.

Bauman, D. E. and W. B. Currie. 1980. Partitioning of nutrients during pregnancy and lactation: A review of mechanisms involving homeostasis and homeorhesis. J. Dairy Sci. 63:15141529.

Birkelo, C. P., D. E. Johnson, and H. P. Phetteplace. 1991. Maintenance requirements of beef cattle as affected by season on different planes of nutrition. J. Anim. Sci. 69:1214-1222.

Broucek, J., K. Kovalcik, D. Gajdosik, and V. Brestensky. 1987. The effect of extreme ambient temperatures on haematological and biochemical indicators in heifers. J. Vet. Med. 32:259-268.

Chen, X., R. Jiang, and Z. Geng. 2012. Cold stress in broiler: Global gene expression analyses suggest a major role of CYP genes in cold responses. Mol. Biol. Rep. 39:425-429.

Christopherson, R. J. 1985. Management and housing of animals in cold environments. In: Stress Physiology in Livestock (Ed. M. K. Yousef). Ungulates, II. CRC Press, Inc., Boca Raton, FL, USA. pp. 175-194.
Delfino, J. G. and G. W. Mathison. 1991. Effects of cold environment and intake level on the energetic efficiency of feedlot steers. J. Anim. Sci. 69:4577-4587.

Elam, C. J. 1970. Problems related to intensive indoor and outdoor beef production systems. J. Anim. Sci. 32:554-559.

Frank, J. W., J. A. Carroll, G. L. Allee, and M. E. Zanelli. 2003. The effects of thermal environment and spray-dried plasma on the acute-phase response of pigs challenged with lipopolysaccharide. J. Anim. Sci. 81:1166-1176.

Ghazavi, A., G. Mosayebi, H. Solhi, M. Rafiei, and S. M. Moazzeni. 2013. Serum markers of inflammation and oxidative stress in chronic opium (Taryak) smokers. Immunol. Let. 153:22-26.

Grzych, M. 2010. Webinar Portal for Forestry and Natural Resources. http://www.forestrywebinars.net/webinars/planningand-design-of-livestock-watering-systems/ Cattle Stress Index Description. Accessed Jun 26, 2014.

Hangalapura, B. N., M. G. Kaiser, J. J. Poel, H. K. Parmentier, and S. J. Lamont. 2005. Cold stress equally enhances in vivo proinflammatory cytokine gene expression in chicken lines divergently selected for antibody responses. Dev. Comp. Immunol. 30:503-511.

Ho, C. H., E. J. Lee, I. Lee, and S. J. Jeong. 2006. Earlier spring in Seoul. Korea Int. J. Climatol. 26:2117-2127.

Kampen, A. H., T. Tollersrud, and A. Lund. 2004. Flow cytometric measurement of neutrophil respiratory burst in whole bovine blood using live Staphylococcus aureus. J. Immunol. Methods 289:47-55.

Khan, M. A., W. M. Dickson, and K. M. Meyers. 1970. The effect of low environmental temperature on plasma corticosteroid and glucose concentrations in the newborn calf. J. Endocrinol. 48:355-363.

Kim, M. H., J. Y. Yang, D. U. Santi, H. J. Lee, C. H. Yun, and J. K. Ha. 2011. The stress of weaning influences serum levels of acute-phase proteins, iron-binding proteins, inflammatory cytokines, cortisol, and leukocyte subsets in Holstein calves. J. Vet. Sci. 12:151-157.

Kizaki, T., H. Yamashita, S. Oh-Ishi, N. K. Day, R. A. Good, and H. Ohno. 1995. Immunomodulation by cells of mononuclear phagocyte lineage in acute cold-stressed or cold-acclimatized mice. Immunology 86:456-462.

Mader, T. L., L. J. Johnson, and J. B. Gaughan. 2010. A comprehensive index for assessing environmental stress in animals. J. Anim. Sci. 88:2153-2165.

Mills, S. E. and B. F. Jenny. 1979. Effects of high concentrate feeding and fasting on plasma glucocorticoids in dairy heifers. J. Anim. Sci. 48:961-965.

Nonnecke, B. J., M. R. Foote, B. L. Miller, M. Fowler, T. E. Johnson, and R. L. Horst. 2009. Effects of chronic environmental cold on growth, health, and select metabolic and immunologic responses of preruminant calves. J. Dairy Sci. 92:6134-6143.

Takahashi, H., H. Murata, and H. Matsumoto. 1986. Responses of plasma insulin, glucagon and cortisol to cold exposure in calves. Nihon Juigaku Zasshi. 48:419-422.

Tsopanakis, C. and C. Tesserommatis. 1991. Cold swimming stress: Effects on serum lipids, lipoproteins and LCAT activity in male and female rats. Pharmacol. Biochem. Behav. 38:813816.

Van Soest, P. J., J. B. Robertson, and B. A. Lewis. 1991. Methods 
for dietary fiber, neutral detergent fiber and nonstarch polysaccharides in relation to animal nutrition. J. Dairy Sci. 74:3583-3597.

Ward, J. R., D. M. Henricks, T. C. Jenkins, and W. C. Bridges. 1992. Serum hormone and metabolite concentrations in fasted young bulls and steers. Domest. Anim. Endocrinol. 9:97-103.

Weber, P. S., T. Toelboell, L. C. Chang, J. D. Tirrell, P. M. Saama, G. W. Smith, and J. L. Burton. 2004. Mechanisms of glucocorticoid-induced down-regulation of neutrophil Lselectin in cattle: evidence for effects at the gene-expression level and primarily on blood neutrophils. J. Leukoc. Biol. 75:815-827.
Webster, A. J. 1970. Direct effects of cold weather on the energetic efficiency of beef production in different regions of Canada. Can. J. Anim. Sci. 50:563-573.

Young, B. A. and R. J. Christopherson. 1974. Effect of prolonged cold exposure on digestion and metabolism in ruminants. In: Livestock Environment. Am. Soc. Agr. Eng., St. Joseph, MI, USA. pp. 75-80.

Young, B. A. 1981. Cold stress as it affects animal production. J. Anim. Sci. 52:154-163.

Young, B. A. 1983. Ruminant cold stress: Effect on production. Can. J. Anim. Sci. 57:1601-1607. 